J. Lake Sci.(湖泊科学), 2020, 32(3): 629-640

DOI 10. 18307/2020. 0304

(c) 2020 by Journal of Lake Sciences

\title{
太湖流域浙江片区出入境水量、水质及污染物通量”
}

\author{
朱昕阳 ${ }^{1}$, 蒋彩萍 ${ }^{2}$, 马晓雁 ${ }^{1}$, 周柯锦 ${ }^{2 * *}$, 贾 佳 $^{3}$, 全炳迁 ${ }^{2}$, 江 蓝 $^{2}$, 许娟娟 ${ }^{2}$, 王 鹏 ${ }^{2}$ \\ (1: 浙江工业大学土木工程学院,杭州 310023) \\ (2: 浙江省环境监测中心, 杭州 310012) \\ (3: 浙江省环境工程技术评估中心,杭州 310000)
}

\begin{abstract}
摘 要: 太湖流域浙江片区受工业和城市废水以及农田地表径流等人为因素的影响, 污染问题日益严重, 根据 2013 年的 水文巡测以及水质监测资料, 分析了太湖流域浙江片区出人境水量和高锰酸盐指数 $\left(\mathrm{COD}_{\mathrm{Mn}}\right)$ 、氨氮 $\left(\mathrm{NH}_{3}-\mathrm{N}\right)$ 、总氮 $(\mathrm{TN})$ 和总磷 (TP) 等水质指标的出人境通量及其时空分布. 结果表明, 2013 年太湖流域浙江片区出人境水量以出境为主, 出人 境断面的首要污染物是 $\mathrm{TN}$, 其平均浓度在各出人境断面均处于 $\mathrm{V} \sim$ 劣 $\mathrm{V}$ 类水平, $\mathrm{COD}_{\mathrm{Mn}} 、 \mathrm{NH}_{3}-\mathrm{N}$ 和 $\mathrm{TP}$ 的平均浓度总体上 达到 II III类标准. 4 种污染物的出人境通量均以出境为主, 研究区域北部是污染物的主要人境断面, 东部是污染物的主 要出境断面. 净出境水量是影响污染物净出境通量的关键因子, 出人境断面水质是净出境通量的主要影响因子. 源头控 制农业面源污染、将工业废水和城镇生活污水处理达标后排放是减轻太湖流域浙江片区水体污染的关键, 是太湖流域水 体污染控制和治理的主要措施.
\end{abstract}

关键词: 太湖流域;水量;水质;污染物通量;相关性分析

\section{Water quantity, quality and pollutant flux of inbound and outbound water in Zhejiang area of Taihu Basin*}

ZHU Xinyang ${ }^{1}$, JIANG Caiping ${ }^{2}$, MA Xiaoyan ${ }^{1}$, ZHOU Kejin $^{2 * *}$, JIA Jia ${ }^{3}$, QUAN Bingqian ${ }^{2}$, JIANG Lan $^{2}$, XU Juanjuan ${ }^{2} \&$ WANG Peng ${ }^{2}$

(1: College of Civil Engineering, Zhejiang University of Technology, Hangzhou 310023, P.R.China)

(2: Zhejiang Province Environmental Monitoring Center, Hangzhou 310012, P.R.China)

(3: Zhejiang Province Environmental Engineering Technology Evaluation Center, Hangzhou 310000, P.R.China)

Abstract: Zhejiang area of Taihu Basin is affected by human factors such as industrial, urban wastewater and farmland surface runoff. Pollution problems are becoming more and more serious. Based on the data of hydrological survey and water quality monitoring in 2013, inbound and outbound water quantity and spatial-temporal distribution of water quality indexes such as permanganate in$\operatorname{dex}\left(\mathrm{COD}_{\mathrm{Mn}}\right)$, ammonia nitrogen $\left(\mathrm{NH}_{3}-\mathrm{N}\right)$, total nitrogen ( TN) and total phosphorus ( TP) in Zhejiang area of Taihu Basin were analyzed. The results showed that the inbound and outbound water quantity in Zhejiang area of Taihu Basin in 2013 was mainly outbound. The primary pollutant in the entry-exit section is TN. The average concentration is in the V-inferior V level in all entry-exit sections. The average concentrations of $\mathrm{COD}_{\mathrm{Mn}}, \mathrm{NH}_{3}-\mathrm{N}$, and $\mathrm{TP}$ generally reach the II - III standard. The outbound and inbound fluxes of the four pollutants are mainly outbound. The northern part of the study area is the main inbound section of pollutants, and the eastern part is the main outbound section of pollutants. The net outbound water quantity is the key factor affecting the net outbound flux of pollutants, and the water quality of the entry-exit section is the main factor affecting the net outbound flux. The key to reducing water pollution in Zhejiang area of Taihu Basin is controlling agricultural non-point source pollution and discharging industrial wastewater and urban domestic sewage after reaching the standard, which is the main measure of water pollution control

* 2019-07-01 收稿; 2019-12-23 收修改稿.

国家自然科学基金项目 (51678527,51878582) 和国家水体污染控制与治理科技重大专项 (2018ZX07208-009) 联合 资助.

** 通信作者;E-mail : zhoukj@ 163.com. 
and treatment in Taihu Basin.

Keywords: Taihu Basin; water quantity; water quality; pollutant flux; correlation analysis

太湖是我国三大淡水湖之一, 是流域内大中城市的重要水源地. 太湖流域浙江片区 $\left(30^{\circ} 08^{\prime} \sim 31^{\circ} 11^{\prime} \mathrm{N}\right.$, $119^{\circ} 14^{\prime} \sim 121^{\circ} 16^{\prime} \mathrm{E}$ ) 西倚天目山脉与安徽省相邻, 南临钱塘江杭州湾, 北滨太湖和江苏省接壤, 东与上海相 连, 地跨杭州、嘉兴和湖州 3 市, 涉及 13 个县级行政区, 流域面积 $12249 \mathrm{~km}^{2}$, 约占太湖流域面积的 $1 / 3$. 包含 山区性河流、平原河网两种典型水系, 水文状况复杂, 并且受潮汐影响, 往复流特征明显. 随着现代经济的迅 速发展, 受工业和城市废水以及农田地表径流等人为因素的影响, 太湖流域污染问题引起了广泛的关

注 $^{[1-5]}$, 水环境污染问题已严重影响太湖流域社会经济和生态环境的和谐和可持续发展. 太湖流域浙江片区 作为太湖流域其中重要的一部分, 其由污染造成的水质性缺水问题依然十分严重. 2014 年起浙江省大力开 展“五水共治”行动,其中“治污水”依旧是五项治水工作中的重点. 本文所研究的水文水质数据年份为 2013 年, 为 “治污水”成果提供了有效的参考. 自 2014 年治水工作开展以来, 浙江省水环境安全趋于好转, 安全指 数呈上升趋势, 2014 年和 2015 年较 2013 年分别提高了 7.38\% 和 $16.85 \%$, 水环境安全从预警状态转为较安 全状态 ${ }^{[6]}$, 水环境质量的明显改善反映了治水工作的成效. 人湖河流是湖泊污染物的主要来源 ${ }^{[7-8]}$, 陆源污 染物随河流输送到湖体会导致湖体富营养化、生态系统受损等一系列环境问题的发生 ${ }^{[9-11]}$, 因此研究主要人 湖河流的水质变化规律、污染物入湖通量及其主要影响因子对湖体污染治理工作具有重要意义 ${ }^{[12-14]}$.

太湖流域浙江片区出人境河道主要分为研究区域西部的安徽人境河道、北部的环太湖河道及与江苏省 交接河道、东部与上海市交接河道以及南部的钱塘江. 本文借鉴湖泊污染物通量分析方法, 根据研究区域主 要河道 2013 年的水文巡测以及水质监测资料, 分析了太湖流域浙江片区出人境水量和高锰酸盐指数 $\left(\mathrm{COD}_{\mathrm{Mn}}\right)$ 、氨氮 $\left(\mathrm{NH}_{3}-\mathrm{N}\right)$ 、总氮 $(\mathrm{TN})$ 和总磷 $(\mathrm{TP}) 4$ 种污染物的出人境通量及其时空分布, 以期为太湖流域 浙江片区水环境治理提供基础数据.

\section{1 太湖流域浙江片区出入境断面水文水质监测及计算方法}

\section{1 水文巡测及水质监测点位选择}

根据年度地表水出人境河道水文巡测资料和浙江省水资源公报等, 按照空间分布在研究区域北部、东 部和南部边界线分别设置水文巡测线, 分别为人湖线、北排线、东排线和钱塘江线; 西部边界上, 主要为流域 分水线, 仅考虑与安徽省交接的河道一一东村港, 断面为东村桥, 除此以外没有其他出人境河流 (图 1). 在 水文巡测线上选取水文巡测断面, 类型分为基点站断面以及巡测站断面, 基点站和巡测站断面流量均为逐 日流量 (由实时流量计算后得到的日平均流量). 其中河流巡测断面的水文数据是由原始水文资料经相关部 门整编后的.

为估算断面通量, 水质监测断面理论上应该与水文监测断面保持一致 ${ }^{[15]}$. 由于本文的水文和水质资料 分别来自水文部门和生态环境部门, 在水文巡测断面所在河道上选取水质监测断面, 空间位置尽量接近, 选 取了 32 个, 具体位置分布如图 1 所示. 各巡测线上的水文巡测断面以及与之对应的水质监测断面详情见 表 1 .

\section{2 首要污染物计算方法}

采用单因子指数法对出人境断面水质进行评估, 单因子污染指数 $\left(P_{i}\right)$ 表示污染物实测浓度与水质标准 的比值, 可通过式 (1) 计算 ${ }^{[16-17]}$ :

$$
P_{i}=\frac{C_{i}}{S_{i}}
$$

式中, $i$ 为污染因子; $C_{i}$ 为污染因子 $i$ 的实测浓度; $S_{i}$ 为污染因子 $i$ 的评价标准值, 采用国家《地表水环境质量 标准》(GB3838-2002) 中的西类水质标准.

\section{3 污染物通量估算方法}

与环太湖河道类似, 太湖流域浙江片区出人境河道流向顺、逆不定, 故污染物通量估算方法根据参考文 献 ${ }^{[18-19]}$ 中报道的方法, 结合 5 种通量估算方法 ${ }^{[20]}$ 优化计算公式. 根据出人境断面水量和水质计算, 由于水质 


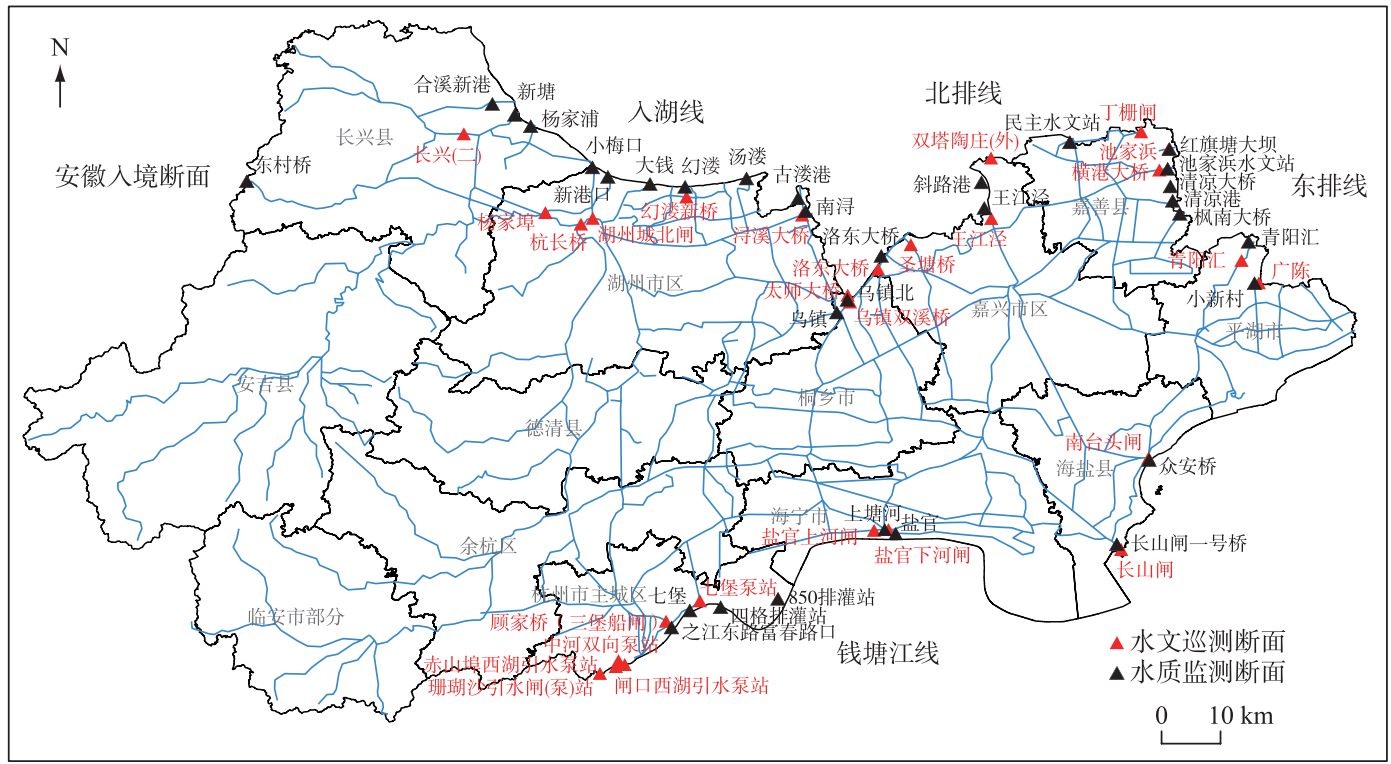

图 1 太湖流域浙江片区地表水出入境水文巡测及水质监测断面

Fig.1 Hydrological survey and water quality monitoring sections of entry-exit surface water in Zhejiang area of Taihu Basin

的监测频次为每月 1 次,故水量按月统计出人境水量. 月通量计算公式为:

$$
\begin{aligned}
W_{i \text { 人境 }} & =K C_{i} \sum_{j=1}^{n} Q_{j \text { 人境 }} \\
W_{i \text { 出境 }} & =K C_{i} \sum_{j=1}^{n} Q_{j \text { 出境 }} \\
W_{i \text { 诤出境 }} & =W_{i \text { 出境 }}-W_{i \text { 人境 }}
\end{aligned}
$$

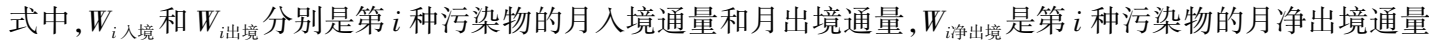

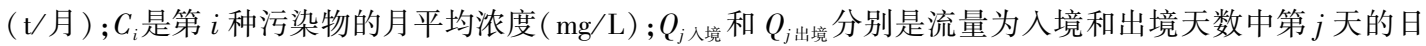
平均流量 $\left(\mathrm{m}^{3} / \mathrm{s}\right) ; n$ 是某个月内日平均流量为人境或出境的天数; $K$ 是单位换算系数, $K=0.0864$.

整个研究区域巡测断面划分为 4 条巡测线和安徽人境断面,逐月统计每条巡测线的出人境水量以及巡 测线上水质监测断面的污染物平均浓度,计算每条巡测线的月出人境污染物通量,将 4 条巡测线的月出人 境污染物通量和从安徽人境的污染物通量相加得到太湖流域浙江片区的月出人境污染物通量, 再将 12 个 月的通量相加,得到太湖流域浙江片区全年的出人境污染物通量.

\section{2 出入境水量变化分析}

2013 年太湖流域浙江片区出入境水量见表 2 , 由于安徽人境断面的日流量数据缺失, 无法逐月统计人 境水量,故引用 2013 年浙江省水资源公报的年度水文数据,年人境水量为 $0.64 \times 10^{8} \mathrm{~m}^{3}$. 因此 2013 年太湖流 域浙江片区人境水量为 $79.20 \times 10^{8} \mathrm{~m}^{3}$, 出境水量为 $145.23 \times 10^{8} \mathrm{~m}^{3}$, 净出境水量为 $66.03 \times 10^{8} \mathrm{~m}^{3} .2013$ 年出人 境水量的年内变化和空间分布情况如图 2 所示.

从出人境水量的时间分布来看, 2013 年各月人境水量相差不大, 各月人境水量占全年人境水量比例范 围为 $6.1 \% \sim 10.6 \%$. 出境水量除了 6 月和 10 月占全年出境水量较大一些, 分别为 $12.1 \% 、 19.5 \%$, 其他月份均 比较接近,占比在 $4.2 \% \sim 8.7 \%$ 之间,且全年各月 (除了 8 月) 出境水量均大于人境水量 (图 2a).

由图 $2 \mathrm{~b}$ 可见,从空间分布来看,太湖流域浙江片区北部的人湖线和北排线以入境为主,其中人湖线人 境水量占全年人境水量的 $46.1 \%$; 北排线人境水量占全年人境水量的 $37.6 \%$. 其次, 钱塘江线人境水量占全 
表 1 太湖流域浙江片区水文巡测及水质监测断面一览表

Tab.1 List of hydrological survey and water quality monitoring sections in Zhejiang area of Taihu Basin

\begin{tabular}{|c|c|c|c|c|c|c|}
\hline $\begin{array}{l}\text { 研究区 } \\
\text { 域边界 }\end{array}$ & 巡测线 & 巡测段 & 基点站 & 单一流量站 & $\begin{array}{l}\text { 水质监测 } \\
\text { 断面个数 }\end{array}$ & 水质监测断面 \\
\hline \multirow[t]{7}{*}{ 北部边界 } & 人湖线 & 长兴(二) 段 & 长兴(二) & $\begin{array}{l}\text { 杨家埠、杭长桥、湖州城 } \\
\text { 北闸 }\end{array}$ & 8 & $\begin{array}{l}\text { 合溪新港、新塘、杨家浦、 } \\
\text { 小梅口、新港口、大钱、幻 } \\
\text { 溇、汤溇 }\end{array}$ \\
\hline & 北排线 & $\begin{array}{c}\text { 幻溇段 } \\
\text { 浔溪大桥段 }\end{array}$ & $\begin{array}{l}\text { 幻溇新桥 } \\
\text { 浔溪大桥 }\end{array}$ & 太师大桥、圣塘桥、双塔 & 8 & $\begin{array}{l}\text { 古溇港、南浔、乌镇、乌镇 } \\
\text { 北、洛东大桥、王江泾、斜 } \\
\text { 路港、民主水文站 }\end{array}$ \\
\hline & & 桐乡段 & 乌镇双溪桥 & & & \\
\hline & & 秀洲西段 & 洛东大桥 & & & \\
\hline & & 秀洲北段 & 王江泾 & & & \\
\hline & & 陶庄段 & 陶庄(外) & & & \\
\hline & & 丁栅段 & 丁栅闸 & & & \\
\hline \multirow[t]{2}{*}{ 东部边界 } & 东排线 & 池家浜段 & 池家浜 & - & 7 & $\begin{array}{l}\text { 池家浜水文站、红旗塘大 } \\
\text { 坝、清凉大桥、清凉港、枫 } \\
\text { 南大桥、青阳汇、小新村 }\end{array}$ \\
\hline & & $\begin{array}{c}\text { 横港大桥段 } \\
\text { 枫泾段 } \\
\text { 平湖北段 } \\
\text { 平湖南段 }\end{array}$ & $\begin{array}{c}\text { 横港大桥 } \\
\text { 青阳汇 } \\
\text { 青阳汇 } \\
\text { 广陈 }\end{array}$ & & & \\
\hline 南部边界 & 钱塘江线 & - & - & 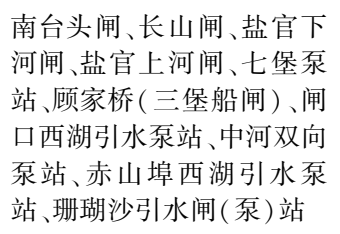 & 8 & $\begin{array}{l}\text { 众安桥、长山闸一号桥、 } \\
\text { 盐官、上塘河、850 排灌 } \\
\text { 站、四格排灌站、七堡、之 } \\
\text { 江东路富春路口 }\end{array}$ \\
\hline 西部边界 ${ }^{1)}$ & - & - & - & 东村桥 & 1 & 东村桥 \\
\hline
\end{tabular}

1) 西部边界上主要为流域分水线,除东村桥断面所在河流以外没有其他出人境河流.

表 22013 年太湖流域浙江片区按月统计出人境水量结果 $\left(\times 10^{8} \mathrm{~m}^{3}\right)$

Tab.2 Monthly statistics of inbound and outbound water volume in Zhejiang area of Taihu Basin in 2013

\begin{tabular}{|c|c|c|c|c|c|c|c|c|c|c|c|c|}
\hline \multirow{2}{*}{ 月份 } & \multicolumn{2}{|c|}{ 人湖线 } & \multicolumn{2}{|c|}{ 北排线 } & \multicolumn{2}{|c|}{ 东排线 } & \multicolumn{2}{|c|}{ 钱塘江线 } & \multicolumn{2}{|c|}{ 安徽人境断面 } & \multicolumn{2}{|c|}{ 合计 } \\
\hline & 人境量 & 出境量 & 人境量 & 出境量 & 人境量 & 出境量 & 人境量 & 出境量 & 人境量 & 出境量 & 人境量 & 出境量 \\
\hline 1 & 3.15 & 0.61 & 2.18 & 3.78 & 0.00 & 7.67 & 0.96 & 0.16 & & & 6.29 & 12.22 \\
\hline 2 & 2.74 & 0.63 & 2.03 & 3.45 & 0.00 & 6.91 & 1.53 & 0.14 & & & 6.30 & 11.13 \\
\hline 3 & 1.97 & 0.84 & 2.16 & 3.89 & 0.01 & 7.69 & 1.19 & 0.19 & & & 5.33 & 12.60 \\
\hline 4 & 2.43 & 0.58 & 1.98 & 3.74 & 0.00 & 5.02 & 1.28 & 0.19 & & & 5.69 & 9.52 \\
\hline 5 & 2.00 & 1.15 & 1.91 & 3.32 & 0.01 & 4.30 & 1.25 & 1.11 & & & 5.18 & 9.87 \\
\hline 6 & 1.48 & 4.23 & 2.78 & 3.44 & 0.00 & 5.64 & 0.57 & 4.20 & - & - & 4.83 & 17.52 \\
\hline 7 & 4.64 & 1.16 & 2.81 & 3.84 & 0.01 & 4.33 & 0.92 & 0.29 & & & 8.37 & 9.62 \\
\hline 8 & 3.88 & 0.45 & 2.77 & 2.94 & 0.43 & 2.26 & 0.91 & 0.46 & & & 8.00 & 6.10 \\
\hline 9 & 3.54 & 0.32 & 2.17 & 2.79 & 0.04 & 3.23 & 0.68 & 0.16 & & & 6.43 & 6.51 \\
\hline 10 & 3.52 & 9.85 & 3.13 & 5.39 & 0.10 & 7.37 & 0.49 & 5.71 & & & 7.23 & 28.33 \\
\hline 11 & 3.98 & 0.68 & 2.95 & 4.04 & 0.05 & 6.31 & 0.94 & 0.54 & & & 7.92 & 11.57 \\
\hline 12 & 3.18 & 0.30 & 2.90 & 3.87 & 0.00 & 5.21 & 0.92 & 0.84 & & & 7.00 & 10.22 \\
\hline 合计 & 36.51 & 20.81 & 29.78 & 44.49 & 0.65 & 65.94 & 11.62 & 13.99 & 0.64 & 0.00 & 79.20 & 145.23 \\
\hline
\end{tabular}


(a) 时间分布

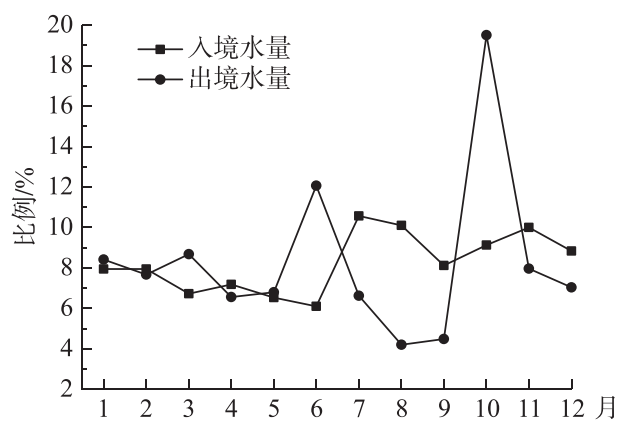

(b) 空间分布

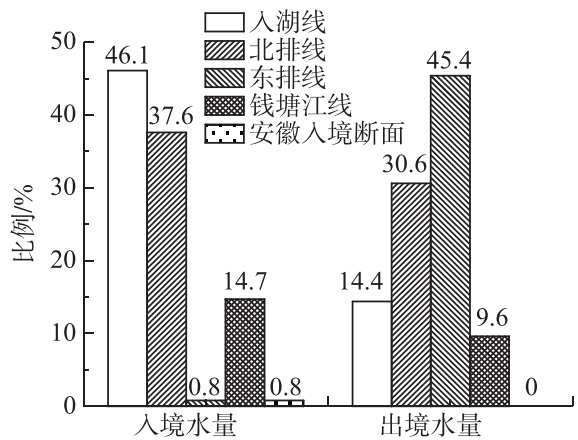

图 22013 年太湖流域浙江片区出人境水量的时空分布

Fig.2 Spatial and temporal distribution of inbound and outbound water volume in Zhejiang area of Taihu Basin in 2013

年人境水量的 $14.7 \%$, 东排线和安徽人境断面全年人境水量相比之下显得很小, 占研究区域全年人境水量的 比例均为 $0.8 \%$. 而人湖线的人境水量较大主要受 “引江济太” 工程抬高太湖水位 ${ }^{[21]}$ 以及年内流域降雨量相 对偏少的影响. 从太湖流域而言, 2013 年流域年降水量比常年减少 $7.4 \%$,年降水频率约为 $66 \%$,但暴雨中心 位于浙西山丘区, 对杭嘉湖平原地区年均水位的提升并不明显, 因此环湖河道太湖倒灌水量的增加是导致 人湖线人境水量增大的重要原因. 地表水出境断面主要是研究区域东部的东排线,占全年出境水量的 $45.4 \%$. 其次是北排线, 占全年出境水量的 $30.6 \%$. 人湖线和钱塘江线出境水量分别占全年出境水量的 $14.4 \%$ 和 $9.6 \%$. 总体来说, 太湖流域浙江片区出入境水量以出境为主, 净出境水量占人境水量的比例达 $83.4 \%$. 由 于研究区域位于杭嘉湖地区, 在降雨过程中河道水位的变化 ${ }^{[22]}$, 对出人境河道水流的流向有一定的影响.

\section{3 出入境断面水质状况分析}

2013 年太湖流域浙江片区 4 条巡测线和安徽人境断面各月的 $\mathrm{COD}_{\mathrm{Mn}} 、 \mathrm{NH}_{3}-\mathrm{N} 、 \mathrm{TN}$ 和 TP 的月平均浓度 如图 3 所示.

由图 3 可见, 从 $\mathrm{COD}_{\mathrm{Mn}}$ 的浓度变化来看, 东排线大多数月份的浓度高于 III 类标准. 人湖线、北排线和钱 塘江线的浓度变化不大, 且普遍低于 III 类标准. 安徽人境断面的 $\mathrm{COD}_{\mathrm{Mn}}$ 浓度变化较大, 变化范围为 $1.60 \sim$ $4.96 \mathrm{mg} / \mathrm{L}$. 从 $\mathrm{NH}_{3}-\mathrm{N}$ 的浓度变化来看, 东排线和钱塘江线大多数月份的浓度明显高于 $1.0 \mathrm{mg} / \mathrm{L}$, 超过 III 类 标准, 并且有部分月份的浓度已经超过 $2.0 \mathrm{mg} / \mathrm{L}$, 为劣 $\mathrm{V}$ 类标准. 北排线的 $\mathrm{NH}_{3}-\mathrm{N}$ 浓度在 III 类标准上下波 动, 人湖线和安徽人境断面各月的 $\mathrm{NH}_{3}-\mathrm{N}$ 浓度均低于 III 类标准. 从 $\mathrm{TN}$ 的浓度变化来看, 各出人境断面的浓 度普遍高于III类标准. 从 TP 的浓度变化来看,东排线和钱塘江线各月的浓度均高于 III 类标准, 北排线的浓 度在 III 类标准上下波动, 人湖线和安徽人境断面各月的浓度均低于 III类标准.

根据水质监测断面污染物的月平均浓度, 计算出 4 条巡测线和安徽人境断面污染物的年平均浓度, 并 依据我国《地表水环境质量标准》(GB3838-2002) 进行水质评价, 评价结果见表 3. 人湖线、北排线以及安徽 人境断面主要污染物指标平均浓度除 $\mathrm{TN}$ 处于 $\mathrm{V} \sim$ 劣 $\mathrm{V}$ 类水平外, $\mathrm{COD}_{\mathrm{Mn}} 、 \mathrm{NH}_{3}-\mathrm{N}$ 和 $\mathrm{TP}$ 平均浓度均达到 II III类标准, 东排线 4 种污染物指标平均浓度均处于 $\mathrm{IV} \sim$ 劣 $\mathrm{V}$ 类水平, 钱塘江线的 $\mathrm{COD}_{\mathrm{Mn}}$ 平均浓度达到 III 类标 准, $\mathrm{NH}_{3}-\mathrm{N} 、 \mathrm{TN}$ 和 $\mathrm{TP}$ 的平均浓度为 $\mathrm{V} \sim$ 劣 $\mathrm{V}$ 类. 结果表明, 4 条巡测线和安徽人境断面的首要污染物均为 $\mathrm{TN}$, 其平均浓度在各出人境断面均处于 $\mathrm{V} \sim$ 劣 $\mathrm{V}$ 类水平. 因此, 出人境河道 $\mathrm{TN}$ 污染的控制和治理对太湖流 域浙江片区来说尤为重要. 总体来说, 研究区域东部东排线以及南部钱塘江线的水质要劣于北部人湖线、北 排线和西部的安徽人境断面, 人湖线、北排线以及安徽人境断面的水质整体上差别不大. 

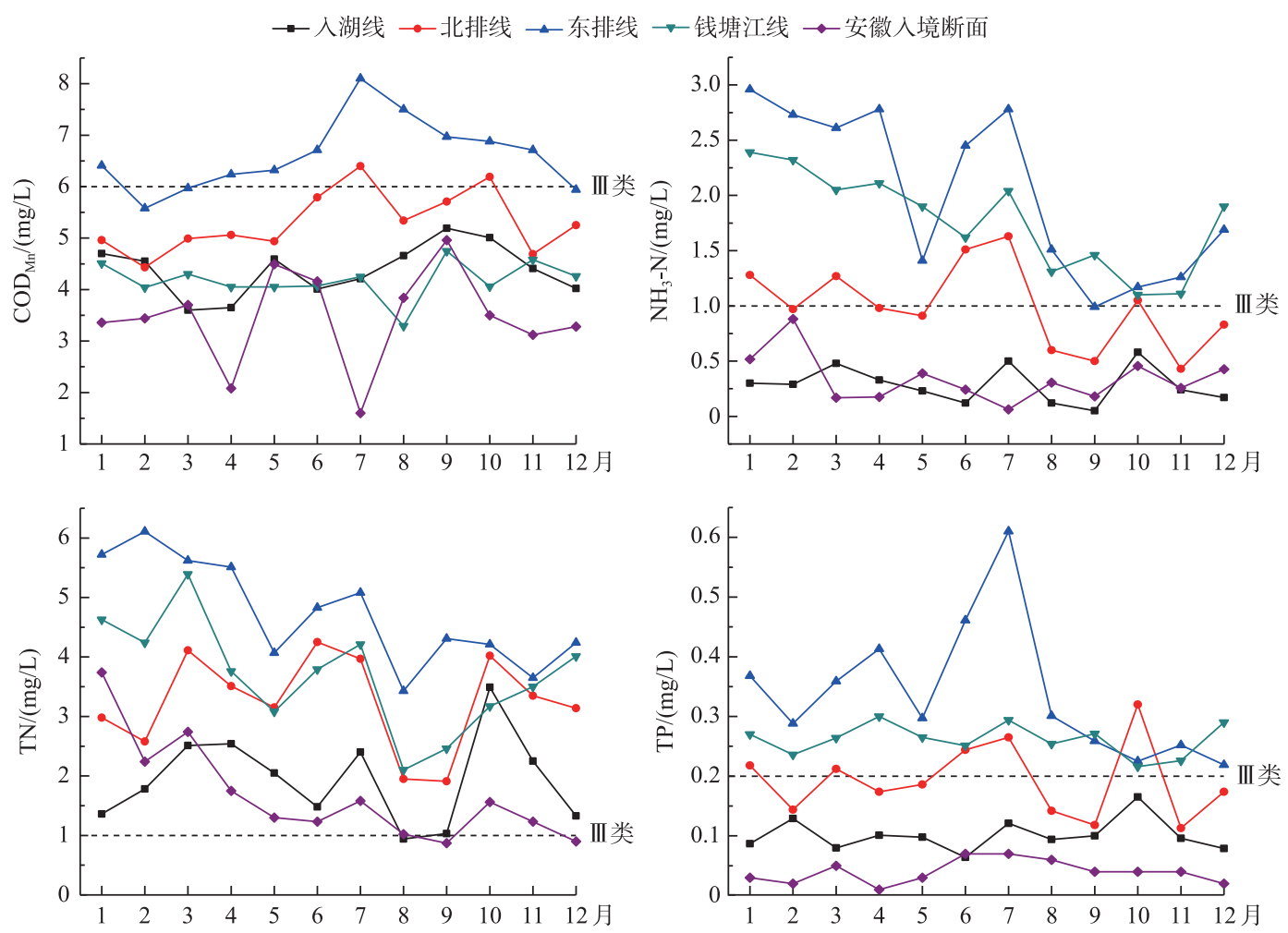

图 32013 年太湖流域浙江片区出人境断面污染物月平均浓度变化情况

Fig. 3 Changes of monthly average concentration of pollutants in entry-exit sections in Zhejiang area of Taihu Basin in 2013

表 32013 年太湖流域浙江片区出人境断面水质评价结果

Tab.3 Water quality assessment results of entry-exit sections in Zhejiang area of Taihu Basin in 2013

\begin{tabular}{ccccccc}
\hline 污染物 & 指标 & 人湖线 & 北排线 & 东排线 & 钱塘江线 & 安徽人境断面 \\
\hline \multirow{2}{*}{$\mathrm{COD}_{\mathrm{Mn}}$} & 浓度 $/(\mathrm{mg} / \mathrm{L})$ & 4.38 & 5.31 & 6.61 & 4.19 & 3.46 \\
& 水质评价结果 & III & III & $\mathrm{IV}$ & III & II \\
$\mathrm{NH}_{3}-\mathrm{N}$ & 浓度 $/(\mathrm{mg} / \mathrm{L})$ & 0.28 & 1.00 & 2.03 & 1.78 & 0.34 \\
& 水质评价结果 & II & III & 劣 $\mathrm{V}$ & $\mathrm{V}$ & II \\
$\mathrm{TN}$ & 浓度 $/(\mathrm{mg} / \mathrm{L})$ & 1.93 & 3.24 & 4.73 & 3.69 & 1.68 \\
& 水质评价结果 & $\mathrm{V}$ & 劣 $\mathrm{V}$ & 劣 $\mathrm{V}$ & 劣 $\mathrm{V}$ & $\mathrm{V}$ \\
$\mathrm{TP}$ & 浓度 $/(\mathrm{mg} / \mathrm{L})$ & 0.10 & 0.19 & 0.34 & 0.26 & 0.04 \\
& 水质评价结果 & II & III & $\mathrm{V}$ & $\mathrm{IV}$ & II \\
\hline
\end{tabular}

\section{4 出入境污染物通量变化分析}

\section{1 出入境污染物年总通量}

根据 2013 年浙江省太湖流域浙江片区出人境断面的水量及水质数据, 计算污染物逐月通过各河道出 人境的通量,得到年总通量 (表 4$)$.

计算结果表明, 2013 年浙江省太湖流域浙江片区出人境污染物通量表现为净出境, 其中 COD $_{\mathrm{Mn}}$ 、 $\mathrm{NH}_{3}-\mathrm{N} 、 \mathrm{TN}$ 和 TP 的净出境通量分别为 44098.36、14996.69、35593.71 和 $2396.00 \mathrm{t} / \mathrm{a}$ (表 4). 考虑到太湖流域 浙江片区的流域面积为 $12249 \mathrm{~km}^{2}$, 将污染物出人境通量换算为单位面积负荷, $\mathrm{COD}_{\mathrm{Mn}} 、 \mathrm{NH}_{3}-\mathrm{N} 、 \mathrm{TN}$ 和 TP 的 
人境单位面积负荷分别为 $3081.84 、 515.25 、 1760.55$ 和 $105.50 \mathrm{~kg} /\left(\mathrm{km}^{2} \cdot \mathrm{a}\right)$, 净出境单位面积负荷分别为 $3600.16 、 1224.32 、 2905.85$ 和 $195.61 \mathrm{~kg} /\left(\mathrm{km}^{2} \cdot \mathrm{a}\right)$. 根据王江飞等 ${ }^{[23]}$ 的相关研究成果, 将 2013 年 TN、TP 的大 气沉降和农业面源人河量之和换算成单位面积负荷分别为 $1737.85 、 114.00 \mathrm{~kg} /\left(\mathrm{km}^{2} \cdot \mathrm{a}\right)$, 与本文计算的出人 境单位面积污染负荷对比来看,分别占人境的 $98.7 \%$ 、108.1\% 和净出境的 $59.8 \% 、 58.3 \%$. 这说明出人境污染 物通量应该作为太湖流域浙江片区污染负荷的一部分,在污染统计分析时将其纳人计算, 可为污染负荷控 制削减和上下游生态补偿等环境管理提供支撑.

表 42013 年太湖流域浙江片区出人境污染物年总通量

Tab.4 Annual total flux of entry-exit pollutants in Zhejiang area of Taihu Basin in 2013

\begin{tabular}{ccccc}
\hline 通量 & $\mathrm{COD}_{\mathrm{Mn}} /(\mathrm{t} / \mathrm{a})$ & $\mathrm{NH}_{3}-\mathrm{N} /(\mathrm{t} / \mathrm{a})$ & $\mathrm{TN} /(\mathrm{t} / \mathrm{a})$ & $\mathrm{TP} /(\mathrm{t} / \mathrm{a})$ \\
\hline 人境量 & 37749.43 & 6311.29 & 21565.02 & 1292.26 \\
出境量 & 81847.79 & 21307.98 & 57158.74 & 3688.26 \\
净出境量 & 44098.36 & 14996.69 & 35593.71 & 2396.00 \\
\hline
\end{tabular}

\section{2 出入境污染物通量的空间分布}

4 条巡测线出入境和安徽入境的污染物通量占研究区域全年出入境污染物通量的比例见表 5 . 各出人 境断面污染物通量基本保持与出入境水量一致的比例, 4 种污染物通过入湖线、北排线、东排线、钱塘江线以 及安徽人境断面流人太湖流域浙江片区的通量比例分别介于 $16.9 \% \sim 43.0 \% 、 42.3 \% \sim 47.0 \% 、 1.1 \% \sim 1.5 \%$ 、 $12.8 \% \sim 34.3 \%$ 和 $0.2 \% \sim 0.6 \%$ 之间, 流出太湖流域浙江片区的通量比例分别介于 $3.9 \% \sim 11.7 \% 、 21.1 \% \sim$ $29.0 \% 、 52.3 \% \sim 65.5 \%$ 和 7.0\% 9.5\% 之间. 由此可以看出, 人湖线和北排线是污染物的主要人境断面, 尤其 是北排线人境污染物通量的比例明显高于其人境水量的比例. 因此, 太湖流域浙江片区人境污染物通量的 主要控制断面是人湖线和北排线. 东排线是污染物的主要出境断面, 4 种污染物的出境通量比例均超过 $50 \%$,其中 $\mathrm{NH}_{3}-\mathrm{N}$ 的出境通量比例高达 $65.5 \%$,东排线交接断面水质达标的要求需要引起重视.

表 52013 年太湖流域浙江片区各出人境断面的污染物通量贡献率 $(\%)$

Tab.5 Contribution rate of pollutant fluxes at entry-exit sections in Zhejiang area of Taihu Basin in 2013

\begin{tabular}{|c|c|c|c|c|c|c|c|c|c|c|}
\hline \multirow{2}{*}{ 断面 } & \multicolumn{2}{|c|}{ 水量 } & \multicolumn{2}{|c|}{$\mathrm{COD}_{\mathrm{Mn}}$} & \multicolumn{2}{|c|}{$\mathrm{NH}_{3}-\mathrm{N}$} & \multicolumn{2}{|c|}{$\mathrm{TN}$} & \multicolumn{2}{|c|}{$\mathrm{TP}$} \\
\hline & 人境 & 出境 & 人境 & 出境 & 人境 & 出境 & 人境 & 出境 & 人境 & 出境 \\
\hline 人湖线 & 46.1 & 14.4 & 43.0 & 11.7 & 16.9 & 3.9 & 32.7 & 9.5 & 29.5 & 7.0 \\
\hline 北排线 & 37.6 & 30.6 & 42.3 & 29.0 & 47.0 & 21.1 & 45.3 & 25.9 & 45.1 & 24.1 \\
\hline 东排线 & 0.8 & 45.4 & 1.3 & 52.3 & 1.5 & 65.5 & 1.1 & 56.2 & 1.5 & 59.8 \\
\hline 钱塘江线 & 14.7 & 9.6 & 12.8 & 7.0 & 34.3 & 9.5 & 20.4 & 8.4 & 23.7 & 9.1 \\
\hline 安徽人境 & 0.8 & - & 0.6 & - & 0.3 & - & 0.5 & - & 0.2 & - \\
\hline
\end{tabular}

\section{3 出入境污染物通量年内变化}

根据 2013 年逐月出人境污染物通量和出人境污染物年总通量, 计算得到出人境污染物通量年内分布 情况 ( 图 4).

由图 4 可见,从污染物人境通量变化来看, 4 种污染物人境通量年内变化大体上比较吻合, 大多数污染 物的逐月人境通量占全年人境通量的比例在 7 月和 10 月较高一些, 在 8 月和 9 月较低一些, 其他月份的比 例尽管上下波动, 但是整体上相差不大. 从污染物出境通量变化来看, 各污染物的逐月出境通量占全年出境 通量的比例变化趋势非常相似, 除了 $\mathrm{NH}_{3}-\mathrm{N}$ 的比例在 1 月最高以外, 其他 3 种污染物出境通量都在 10 月的 比例最高, 其次是 1 月、 3 月和 6 月的比例较高一些, 而 8 月和 9 月的比例相对来说要低一些. 这可能是由于 比例较高的月份正值梅雨期或台汛期, 期间降雨量增大, 出人境水量相比其他月份较大, 影响到出人境污染 物通量的变化, 因此本文深人分析了水质、水量和污染物通量三者之间的相关性, 通过相关性分析去了解水 质和水量对污染物通量估算的影响程度. 

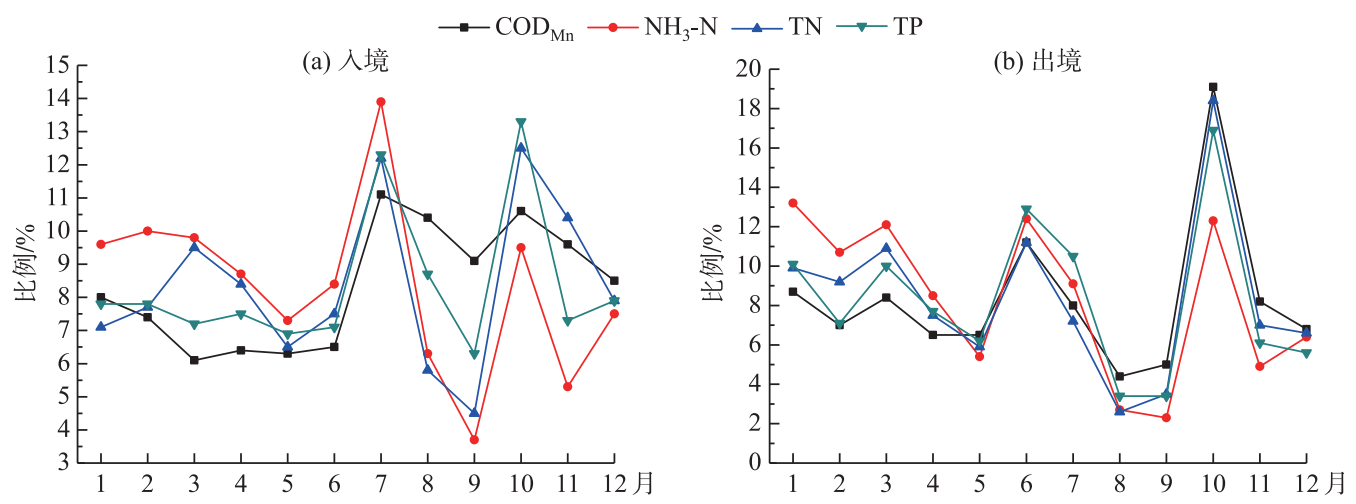

图 42013 年太湖流域浙江片区出人境污染物通量年内分布情况

Fig.4 Distribution of entry-exit pollutant fluxes in Zhejiang area of Taihu Basin in 2013

\section{4 水质水量相关性分析}

2013 年太湖流域浙江片区 4 条巡测线上各污染物逐月的平均浓度与净出境水量的相关关系如图 5 所示.
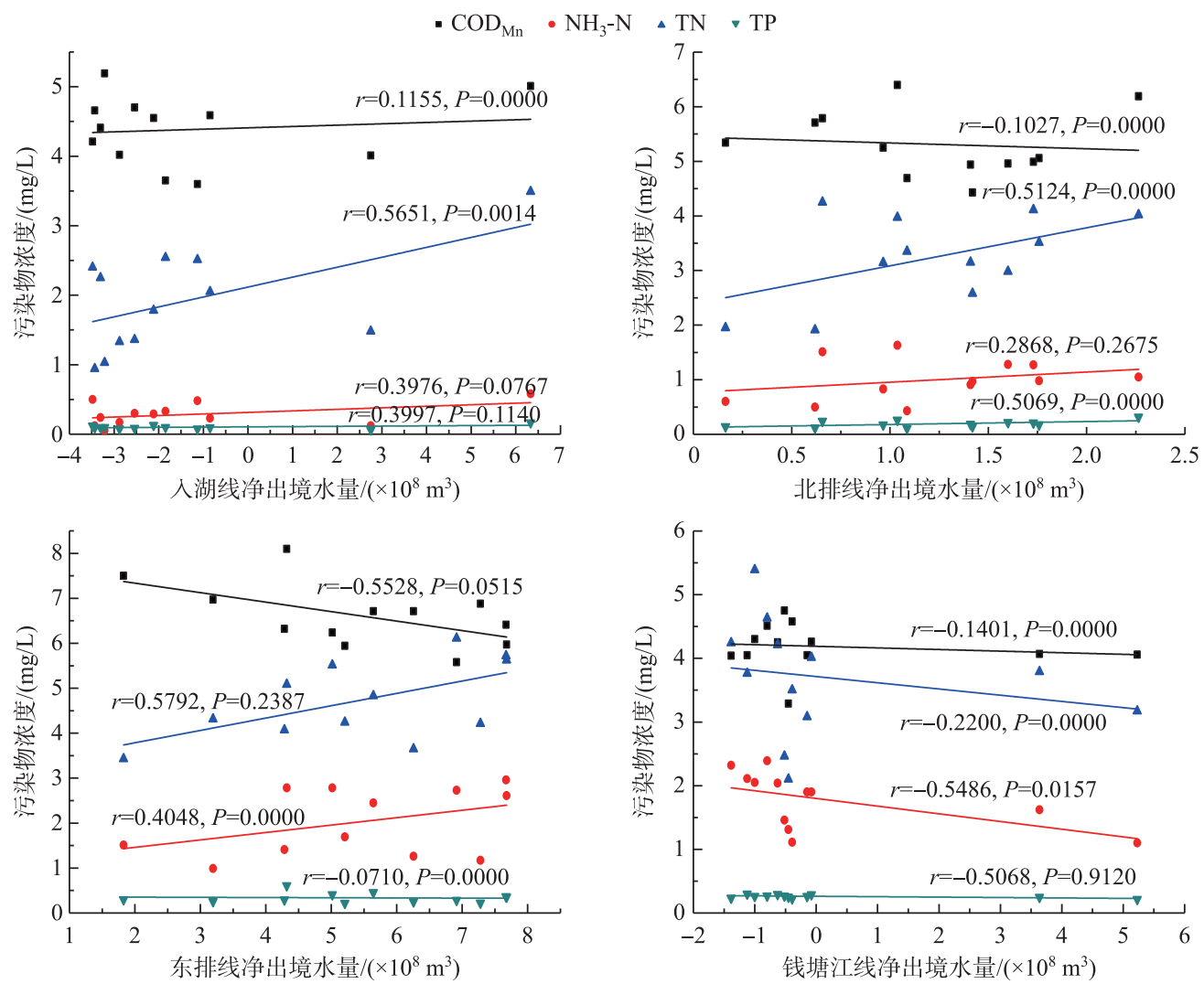

图 52013 年太湖流域浙江片区水质与水量的相关关系

Fig.5 The correlation between water quality and quantity in Zhejiang area of Taihu Basin in 2013

由图 5 可见, 入湖线 $\mathrm{TN}$ 的浓度与水量呈极显著正相关 $(r=0.5651, P<0.01)$, 说明 $\mathrm{TN}$ 污染来源可能以非点 源为主, 其产生量与径流量的大小呈正比, 年内径流量的变化会改变断面的污染物通量, 而污染物浓度则会出 现增加、减少、不变的多种可能性, 浓度多与流量呈正相关. $\mathrm{COD}_{\mathrm{Mn}}$ 的浓度与水量基本不相关, 相关系数很小 
$(r=0.1155), \mathrm{NH}_{3}-\mathrm{N}$ 和 TP 的浓度与水量无显著相关性 $(P>0.05)$, 说明三者的污染可能受点源、非点源共同影 响, 年内径流量的变化会改变断面的污染物通量, 也会改变污染物浓度, 浓度与流量较为复杂, 可能呈正相关、 负相关、无关的情况. 北排线 TN 和 TP 的浓度与水量呈极显著正相关, $\mathrm{COD}_{\mathrm{Mn}}$ 的浓度与水量不相关, $\mathrm{NH}_{3}-\mathrm{N}$ 的 浓度与水量无显著相关性. 东排线 $\mathrm{NH}_{3}-\mathrm{N}$ 的浓度与水量呈极显著正相关, $\mathrm{TP}$ 的浓度与水量不相关, $\mathrm{COD}_{\mathrm{Mn}}$ 和 $\mathrm{TN}$ 的浓度与水量无显著相关性. 钱塘江线 $\mathrm{NH}_{3}-\mathrm{N}$ 的浓度与水量呈显著负相关 $(r=-0.5486, P<0.05)$, 其污染来 源可能以点源为主, 年内径流量的变化不会对断面的污染物通量有太大的影响, 只会改变污染物浓度, 浓度多 与流量呈负相关. $\mathrm{COD}_{\mathrm{Mn}}$ 和 $\mathrm{TN}$ 的浓度与水量不相关, $\mathrm{TP}$ 的浓度与水量无显著相关性.

由以上分析可知, 4 条巡测线上各污染物浓度与水量的相关性在一定程度上能反映其污染来源类型的 情况, 为不同控制线上各污染物的针对性治理提供一定的参考. 但是也存在局限性, 根据富国 ${ }^{[20]}$ 对污染物 浓度和径流量变化呈正相关、负相关和无关 3 种关系极端情况的阐述, 比如通过浓度和水量呈负相关的关 系去判断某污染物来源为点源时, 需要假定断面上游流域内点源排放的该污染物质的数量年内为恒定值, 且无非点源来源. 通过浓度和水量呈正相关的关系去判断某污染物为非点源时, 需要假定断面上游流域内 点源排放的该污染物质为零. 大部分污染物很难存在这种极端的情况, 所以污染物的来源一般既有点源, 又 有非点源, 只是占比不同而已. 因此, 要估算时段通量, 在时段通量的估算方法上对点源、非点源的处理有一 个主观或经验的判断. 这也成为污染物通量估算当中不可忽略的一个影响因素.

\section{5 污染物通量与水质、水量的相关性分析}

污染物通量估算的误差主要来源于水质、水量、采样点的代表性、水质分析方法和监测频率等因素 ${ }^{[24]}$, 而水质和水量是影响污染物通量的 2 个主要因素, 通过相关性分析可以了解其对污染物通量的影响, 进而
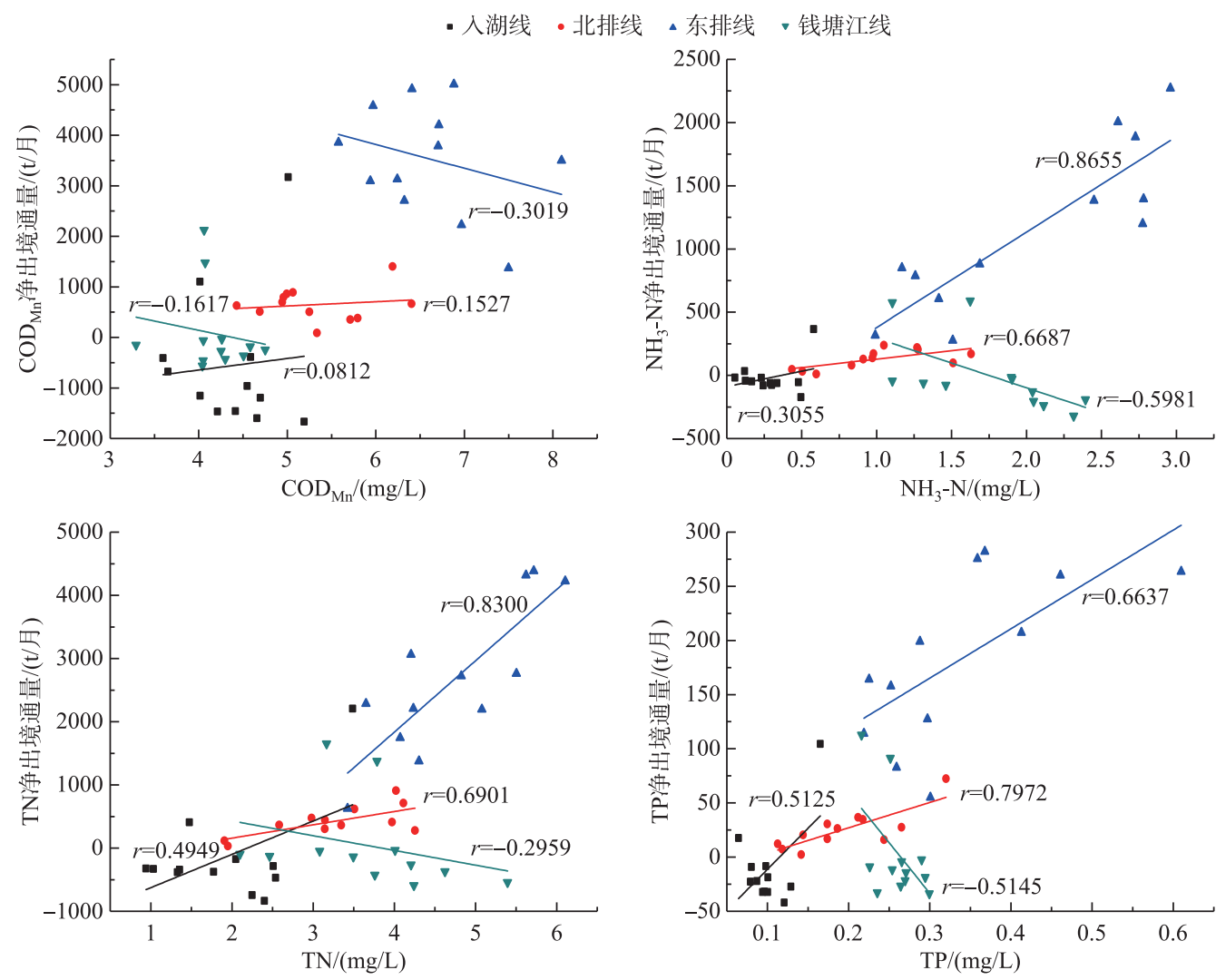

图 62013 年太湖流域浙江片区各污染物净出境通量与浓度的相关关系

Fig.6 The correlation between net outbound flux and concentration of pollutants in Zhejiang area of Taihu Basin in 2013 
找出污染物通量的关键影响因子.

2013 年太湖流域浙江片区 4 条巡测线上各污染物逐月净出境通量与出人境断面水质的相关性分析如 图 6 所示. 4 条巡测线的污染物净出境通量与 $\mathrm{NH}_{3}-\mathrm{N} 、 \mathrm{TN}$ 和 TP 浓度的相关性一般, 相关系数的绝对值在 0.2959 0.8655 之间,与 $\mathrm{COD}_{\mathrm{Mn}}$ 的相关性较差, 相关系数的绝对值在 $0.0812 \sim 0.3019$ 之间.

2013 年太湖流域浙江片区 4 条巡测线上各污染物逐月的净出境通量与净出境水量的相关系数分析如 图 7 所示. 各污染物净出境通量与净出境水量之间的相关性较好,相关系数在 $0.6844 \sim 0.9997$ 之间.

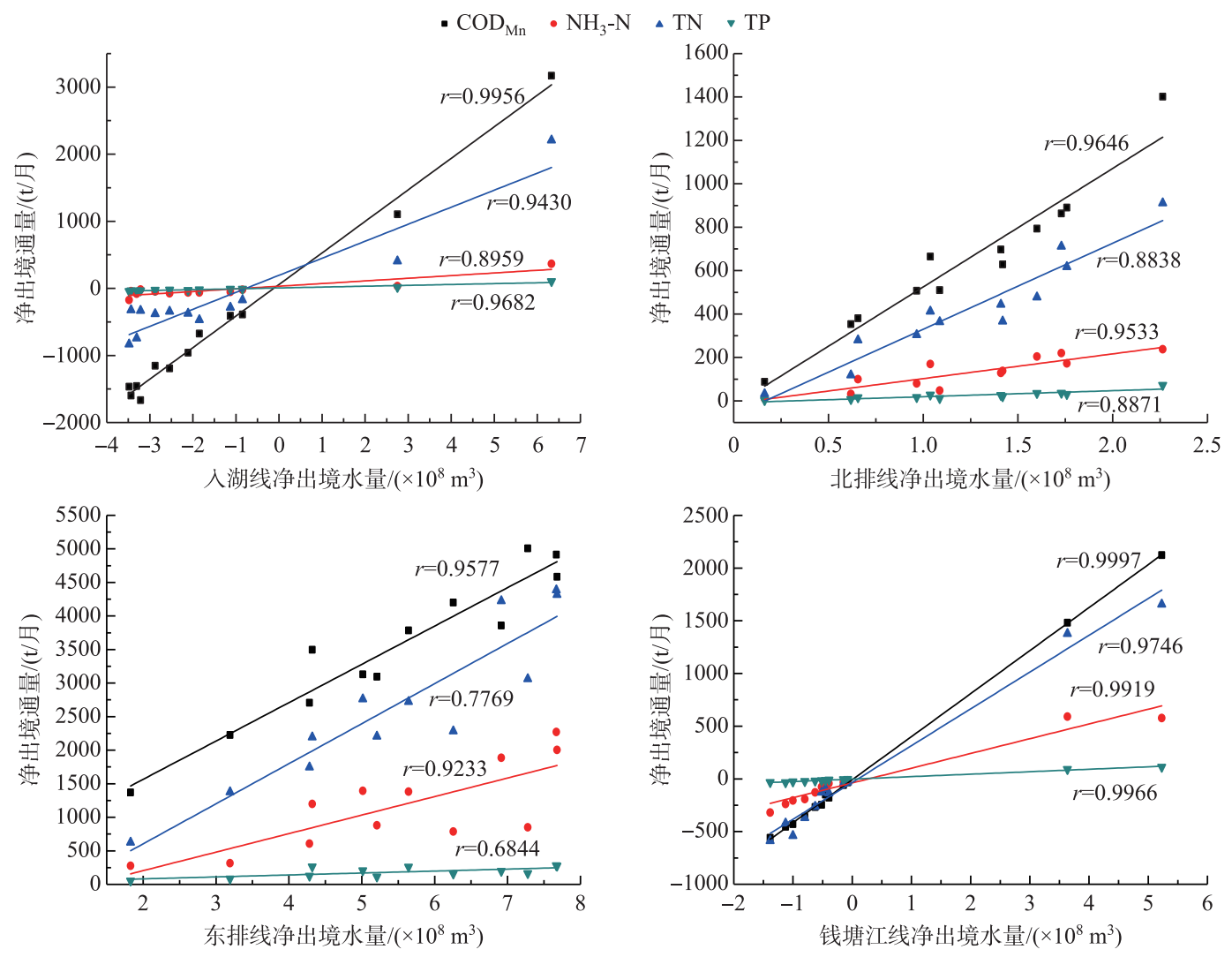

图 72013 年太湖流域浙江片区各污染物净出境通量与水量的相关关系

Fig. 7 The correlation between net outbound flux of pollutants and water volume in Zhejiang area of Taihu Basin in 2013

通过水质、净出境水量与污染物净出境通量的相关性分析可以看出, 净出境水量是影响污染物净出境 通量的关键因子, 而出人境断面水质则是净出境通量的主要影响因子, 这与李卫平等 ${ }^{[25]}$ 的研究结果一致.

水量的变化是人为无法控制的,水质受点源和面源污染共同影响. 点源污染主要是工业废水和城镇生 活污水未经处理或处理未达标排放到河道导致的水体污染,面源污染主要是降雨冲刷地面形成的地表径流 将各类污染物挟带人河道引起的水体污染, 因此源头控制农业面源污染、将工业废水和城镇生活污水处理 达标后排放是减轻太湖流域浙江片区水体污染的关键之举.

\section{5 结论}

1) 2013 年太湖流域浙江片区出人境水量以出境为主. 全年各月出人境水量变化不大, 其中人湖线和北 排线以人境为主,东排线以出境为主. 杭嘉湖地区降雨过程对出人境河道水流的流向有一定的影响.

2) 太湖流域浙江片区出人境断面的首要污染物是 $\mathrm{TN}$, 其平均浓度在各出人境断面均处于 $\mathrm{V} \sim$ 劣 $\mathrm{V}$ 类 
水平, $\mathrm{COD}_{\mathrm{Mn}} 、 \mathrm{NH}_{3}-\mathrm{N}$ 和 TP 的平均浓度总体上达到 II III 类标准. 出人境河道 $\mathrm{TN}$ 污染的控制和治理对太湖 流域浙江片区来说尤为重要.

3) $\mathrm{COD}_{\mathrm{Mn}} 、 \mathrm{NH}_{3}-\mathrm{N} 、 \mathrm{TN}$ 和 TP 的出人境通量均以出境为主, 人湖线和北排线是污染物的主要人境断面, 东排线是污染物的主要出境断面. 因此东排线交接断面水质达标的要求需要引起重视,在出人境通量较高 的月份需要关注各出人境断面的水质变化情况.

4) 净出境水量是影响污染物净出境通量的关键因子, 出人境断面水质是净出境通量的主要影响因子. 太湖流域浙江片区水质受点源和面源污染共同影响,源头控制农业面源污染、将工业废水和城镇生活污水 处理达标后排放是减轻水体污染的关键之举.

\section{6 参考文献}

[ 1 ] Lv ZL. Practice and thoughts on comprehensive treatment of water pollution in Lake Taihu. Journal of Hohai University: Natural Sciences, 2012, 40(2) : 123-128. [吕振霖. 太湖水环境综合治理的实践与思考. 河海大学学报: 自然科学 版, 2012, 40(2): 123-128.]

[ 2 ] Dai XL, Qian PQ, Ye L et al. Changes in nitrogen and phosphorus concentrations in Lake Taihu, 1985-2015. J Lake Sci, 2016, 28(5) : 935-943. DOI: 10.18307/2016.0502. [戴秀丽, 钱佩琪, 叶凉等. 太湖水体氮、磷浓度演变趋势 (1985-2015 年). 湖泊科学, 2016, 28(5): 935-943.]

[ 3 ] Yi J, Xu F, Gao Y et al. Variations of water quality of the major 22 inflow rivers since 2007 and impacts on Lake Taihu. $J$ Lake Sci, 2016, 28(6) : 1167-1174. DOI: 10.18307/2016.0602. [易娟, 徐枫, 高怡等. 2007 年以来环太湖 22 条主 要河流水质变化及其对太湖的影响. 湖泊科学, 2016, 28(6): 1167-1174.]

[ 4 ] Zhang T, Chen QW, Yi QT et al. Spatial and seasonal variations of water quality in the upstream plain river networks of the Taihu Basin. J Lake Sci, 2017, 29(6) : 1300-1311. DOI : 10.18307/2017.0602. [张涛, 陈求稳, 易齐涛等. 太湖 流域上游平原河网区水质空间差异与季节变化特征. 湖泊科学, 2017, 29(6)：1300-1311.]

[ 5 ] Zhu W, Tan YQ, Wang RC et al. The trend of water quality variation and analysis in typical area of Lake Taihu, 20102017. J Lake Sci, 2018, 30(2) : 296-305. DOI: 10.18307/2018.0202. [ 朱伟, 谈永琴, 王若辰等. 太湖典型区20102017 年间水质变化趋势及异常分析. 湖泊科学, 2018, 30(2): 296-305. ]

[ 6 ] He YF, Li WJ, Chen J et al. Evaluation and alert of water environment security before and after "Five-Water-Governance” in Zhejiang province. Journal of Zhejiang University: Science Edition, 2018, 45(2): 234-241. [何月峰, 李文洁, 陈佳 等. 浙江省“五水共治”决策前后水环境安全评估预警. 浙江大学学报: 理学版, 2018, 45(2): 234-241.]

[ 7 ] Li LQ, Shan BQ, Yin CQ. Stormwater runoff pollution loads from an urban catchment with rainy climate in China. Frontiers of Environmental Science \& Engineering, 2012, 6( 5) : 672-677.

[ 8 ] Luo LC, Qin BQ, Yang LY et al. Total inputs of phosphorus and nitrogen by wet deposition into Lake Taihu, China. Hydrobiologia, 2007, 581(1) : 63-70.

[ 9 ] Zhou JL. Fluxes of organic contaminants from the river catchment into, through and out of the Humber Estuary, UK. Marine Pollution Bulletin, 1999, 37(3-7) : 330-342.

[10] Zhou MJ, Shen ZL, Yu RC. Responses of a coastal phytoplankton community to increased nutrient input from the Changjiang (Yangtze) River. Continental Shelf Research, 2008, 28(12) : 1483-1489.

[11] Gao X, Song J. Phytoplankton distributions and their relationship with the environment in the Changjiang Estuary, China. Marine Pollution Bulletin, 2005, 50(3) : 327-335.

[12] Bao X, Watanabe M, Wang QX et al. Nitrogen budgets of agricultural fields of the Changjiang River basin from 1980 to 1990. Science of the Total Environment, 2006, 363(1/2/3): 136-148.

[13] Gao L, Li DJ, Ding PX. Nutrient budgets averaged over tidal cycles off the Changjiang( Yangtze River) Estuary. Estuarine Coastal and Shelf Science, 2008, 77(3): 331-336.

[14] Grimvall A. Time scales of nutrient losses from land to sea a European perspective. Ecological Engineering, 2000, 14(4): 363-371.

[ 15] He XJ, Wang B, Liu GY et al. Water quality, quantity and pollutant fluxes variations of the rivers surrounding Lake Taihu in Zhejiang Province during hydrological year of 2010-2011. J Lake Sci, 2012, 24(5) : 658-662. DOI: 10.18307/2012. 0502. [ 何锡君, 王贝, 刘光裕等. 2010-2011 水文年浙江省环太湖河道水质水量及污染物通量. 湖泊科学, 2012, 
24(5): 658-662.]

[16] Yang Z, Zhong XH, Ci XB et al. Research on pollutant discharge loads from Tiaoxi to Taihu. Journal of Zhejiang University: Science Edition, 2013, 40(2) : 196-200. [杨哲, 钟晓辉, 次新波等. 苕溪污染物人湖通量研究. 浙江大学学报: 理学版, 2013, 40(2) : 196-200.]

[17] Liu GH, Fu BJ, Yang P. Quality of aquatic environment at haihe river and the pollutant fluxes flowing into sea. Environmental Science, 2001, 22(4): 46-50. [刘国华, 傅伯杰, 杨平. 海河水环境质量及污染物人海通量. 环境科学, $2001,22(4): 46-50$.

[18] Zhai SH, Zhang HJ. Water quantity and waste load variation of rivers around Lake Taihu from 2000 to 2002. J Lake Sci, 2006, 18(3) : 225-230. DOI: 10.18307/2006.0305. [翟淑华, 张红举. 环太湖河流进出湖水量及污染负荷 $(2000-$ 2002 年). 湖泊科学, $2006, \mathbf{1 8}(3): 225-230$.

[19] Ma Q, Liu JJ, Gao MY. Amount of pollutants discharged into Lake Taihu from Jiangsu Province, 1998-2007. J Lake Sci, 2010, 22(1) : 29-34. DOI: 10.18307/2010.0104. [马倩, 刘俊杰, 高明远. 江苏省人太湖污染量分析 ( 1997-2007 年). 湖泊科学, $2010,22(1): 29-34$. ]

[20] Fu G. Analysis of the estimation methods for the river pollutant fluxes ( I ) : Comparison and analysis of the estimation methods of period fluxes. Research of Environmental Sciences, 2003, 16(1) : 1-4. DOI: 10.13198/j.res. 2003.01.3.fug. 001. [富国. 河流污染物通量估算方法分析( I ) 一一时段通量估算方法比较分析. 环境科学研究, 2003, 16(1): 1-4.]

[21] Wu YK, Tao YG, Wang HY. Influence of “Diverting Changjiang River water into Taihu Lake” engineering to Zhejiang. Zhejiang Hydrotechnics, 2007, (6) : 13-15, 18. [伍远康, 陶永格, 王红英. “引江济太” 工程对浙江的影响分析. 浙 江水利科技, 2007, (6): 13-15, 18.]

[22] Wang J, Xu YP, Wang YF et al. Impacts of anthropogenic activity on the response of water level to rainfall in the urbanized plain river network: A case study in the Hangzhou-Jiaxing-Huzhou region of Taihu Basin. J Lake Sci, 2019, 31(3) : 779-787. DOI: 10.18307/2019.0316. [王杰, 许有鹏, 王跃峰等. 平原河网地区人类活动对降雨一水位关系的影 响——太湖流域杭嘉湖地区为例. 湖泊科学, 2019, 31(3): 779-787.]

[23] Wang JF, Zhou KJ, Wang XQ et al. Atmospheric nitrogen and phosphorous deposition in Hangjiahu area. China Environmental Science, 2015, 35(9): 2754-2763. [王江飞, 周柯锦, 汪小泉等. 杭嘉湖地区大气氮、磷沉降特征研究. 中国 环境科学, 2015, 35(9): 2754-2763.]

[24] Ji XM, Wen L, Zhang M et al. Analysis of pollutant flux into Lake Hongze. Jiangsu Water Resources, 2014, ( 7) : 45-46, 48. [纪小敏, 闻亮, 张鸣等. 洪泽湖人湖污染物通量分析. 江苏水利, 2014, (7): 45-46, 48.]

[25] Li WP, Chen AH, Yu LH et al. Pollutant influx from the main river (Kherlen River) of Lake Hulun in wet seasons, 2010-2014. J Lake Sci, 2016, 28(2) : 281-286. DOI: 10.18307/2016.0206. [李卫平, 陈阿辉, 于玲红等. 呼伦湖主 要人湖河流克鲁伦河丰水期污染物通量 (2010-2014). 湖泊科学, 2016, 28(2) : 281-286.] 